\title{
Do B chromosomes affect morphometric characters in yellow-necked mice Apodemus flavicollis (Rodentia, Mammalia)?
}

\author{
Jelena BLAGOJEVIĆ and Mladen VUJOŠEVIĆ
}

\begin{abstract}
Blagojević J. and Vujošević M. 2000. Do B chromosomes affect morphometric characters in yellow-necked mice Apodemus flavicollis (Rodentia, Mammalia)? Acta Theriologica 45: 129-135.

The presence of B chromosomes in the yellow-necked mouse Apodemus flavicollis (Melchior, 1834) was analyzed in 320 adult animals from four localities in Yugoslavia. Our aim was to assess the effects of B chromosomes on certain morphometric characteristics. The characters that were chosen are included in the taxonomic discrimination of this particular species as well as the sibling species Apodemus sylvaticus (Linnaeus, 1758). B chromosomes were found in all the localities with frequencies ranging from $21.6 \%$ to $42.9 \%$. It was ascertained that different frequencies of animals with B chromosomes change the slope of the regression curve of the length of foramina incisiva (FI) relative to the distance from the 3rd upper molar to the incisor (IM3). This finding questions the validity of use of this relative value in taxonomy without taking into consideration karyological data. It was also established that the relative length of the tail (the body/tail ratio) significantly increase in the presence of B chromosomes. As this index demonstrates significant geographic variability the result could be taken as a trend only.
\end{abstract}

Department of Genetics, Institute for Biological Research, 29. novembra 142, 11060 Belgrade, Yugoslavia, e-mail: jelenabl@ibiss.bg.ac.yu and mladenvu@ibiss.bg.ac.yu

Key words: Apodemus flavicollis, B chromosomes, morphometric characters, taxonomy, discriminating characters

\section{Introduction}

B chromosomes represent an intriguing, heterogeneous class of chromosomes that are found in all phyla, except birds. The heterogeneous nature of $\mathrm{B}$ chromosomes is best illustrated by the fact that their only common characteristic is that they are nonessential. Numerous effects of B chromosomes have been described, especially in plant and insect populations. This is not the case with mammals where B chromosomes were found in only 34 species (Vujošević 1993), out of which five belong to the genus Apodemus Kaup, 1829. Polymorphism of B chromosomes was studied in detail in two of them: A. peninsulae Thomas, 1907 (Vorontsov et al. 1977) and A. flavicollis (Melchior, 1834) (Vujošević et al. 1991, Zima and Macholán 1995). 
However, not enough attention has been devoted to the effects of $\mathrm{B}$ chromosomes. Studies of seasonal changes in B chromosome frequencies (Blagojević and Vujošević 1995, Vujošević and Blagojević 1995) indicate that B chromosomes exert effects at the level of animal populations. Populations with Bs are widespread in A. flavicollis and are present in different frequencies, up to 93.5\% (Zima and Macholán 1995). In contrast, in sibling species A. sylvaticus (Linnaeus, 1758), Bs are found in small frequencies in only a few populations (Vujošević and Živković 1987, Zima and Macholán 1995, Zima et al. 1997). It should be noted that both species belong to the subgenus Sylvaemus Ognev and Vorobiev, 1923, they share the same habitats in most parts of their distribution, and even live sympatrically in some areas (Niethammer 1969). In some parts of their range (southeastern Europe) it is very difficult to make a morphological distinction between them as differences in morphological characters between populations of the same species are of the same magnitude as differences between species. Due to these problems different sets of discriminating characters are used for different parts of the areal. In general A. flavicollis has a longer tail than body and longer hind feet and ears than A. sylvaticus (Ruprecht 1979, Görner and Hackethal 1987). With the aim of improving the characterization of these species in southern parts of their areal, Tvrtković (1979) introduced the use of bivariate plots of the length of foramina incisiva (FI) to the distance from the 3rd upper molar to the incisor (IM3). This method was, according to Kryštufek and Stojanovski (1996), successively used in the Balkan areal.

The aim of this paper was to establish whether the presence of B chromosomes in populations of $A$. flavicollis in the southern part of its areal affect certain morphometric characters used for species determination.

\section{Material and methods}

The yellow-necked mouse Apodemus flavicollis (Melchior, 1834), were collected in Yugoslavia between 1989 and 1997 at four localities (UTM coordinates are given in brackets): the Jastrebac (EP-30) and Cer mountains (CQ-75), Lešnica (CQ-64) and Ada (CQ-64). For analysis 320 adult animals were taken: Jastrebac 182 (F 98 and M 84), Cer 55 (F 28 and M 27), Lešnica 32 (F 12 and M 20) and Ada 51 (F 19 and M 32). The age of the animals was determined according to Felten (1952).

Chromosomes were prepared from bone marrow according to the standard procedure. The number of chromosomes was determined by scoring 30 metaphases per animal. G- and C-banding were performed essentially as described by Seabright (1971) and Summner (1972).

Immediately after sacrifice the tail and body lengths (with head) were measured. For comparisons of groups of animals the relative tail lengths were expressed as the body/tail length (B/T). The hind feet (HFL) and ear lengths (EL) were measured with $0.05 \mathrm{~mm}$ accuracy. The following measurements were taken on the skulls: the length of foramina incisiva (FI), and the distance from the 3rd upper molar to the upper incisor (IM3). FI was measured under the dissecting microscope (16-fold magnification). IM3 was measured with a vernier caliper with an accuracy to the nearest $0.05 \mathrm{~mm}$. The HFL, EL, FI and IM3 characters were measured on both left and right sides and their means calculated. Statistical analysis was performed using STATISTICA for Windows ver. 4.5. 


\section{Results and discussion}

The standard karyotype of A. flavicollis is composed of 48 acrocentric chromosomes of decreasing size. B chromosomes are also acrocentrics and of the same size as the smallest chromosomes of the normal set (Vujošević and Živković 1987). Karyotype analysis revealed that Bs were present in all the studied samples. The distribution of G-and C-bands were not different from that on A chromosomes. The frequency of animals with B chromosomes varied from 21.6\% at the Ada to $42.9 \%$ on Jastrebac (Table 1). In pooled samples of B carriers, $73.9 \%$ of the animals had one B chromosome, $20.9 \%$ had two, $4.3 \%$ had three, and only one animal had five B chromosomes $(0.9 \%)$. Five B chromosomes in one animal is the highest number observed in populations from Yugoslavia (Blagojević and Vujošević 1991).

The mean values of the analyzed characters in animals with $(\mathrm{B}+)$ and without (B0) B chromosomes did not differ significantly (one-way ANOVA), except the relative tail length $(\mathrm{B} / \mathrm{T}) F=6.35, \mathrm{df}=1,277, p<0.02$. Significant differences in relative tail length were obtained $(F=6.39, \mathrm{df}=2,276, p<0.005)$ when groups of animals without, with one, and more then one $\mathrm{B}$ chromosome were compared in the pooled sample. Carriers of one $B$ chromosome $(B / T=1.12)$ were separated from groups of animals without $(\mathrm{B} / \mathrm{T}=1.07)$ and with more then one $\mathrm{B}$ chromosome $(\mathrm{B} / \mathrm{T}=1.06)$. Although significant heterogeneity (Levene's test) among samples exist ( $F=3.53$, df $=3,275, p<0.02$ ), the observed trend is interesting as Zima and Macholán (1995) discovered that animals with B chromosomes were significantly heavier than those without B's (in pooled sample from North Bohemia to Turkey).

It is worth mentioning that significant differences between sexes in whole samples for the mean values of the analyzed characters were obtained for hind feet and foramina incisiva lengths. For both characters the values were significantly higher in males. The test for homogeneity of the variances showed that there were no differences for foramina incisiva $(F=2.33, \mathrm{df}=3,317, \mathrm{~ns})$ and the distance from the 3rd upper molar to the upper incisor $(F=2.53$, df $=3,317, \mathrm{~ns})$ among the different localities.

The correlation diagram between FI and IM3 (Fig. 1) clearly indicates a difference between groups of animals with and without Bs in whole samples. The coefficient of regression was higher in the group of animals with B chromosomes $(b=0.273)$ then in the group without Bs $(b=0.124)$. The ratio between FI and IM3 was used for discriminating between A. sylvaticus and A. flavicollis in taxonomic studies (Tvrtković 1979, Kryštufek and Stojanovski 1996). Regression curves were parallel, without any overlap, which made possible the accurate discrimination between the two species. However, we found that the presence of specimens with $B$ chromosomes can significantly change the slope of the regression curve which in turn decreases the discriminative value of this relative ratio.

As differences in the frequency of Bs on the studied localities exist, correlation diagrams between FI and IM3 were compared on each locality separately (Fig. 2). Correlation between FI and IM3 was significant (at 5\% level) on all localities 
Table 1. Results of one-way ANOVA ( $F$ value) between animals without $(\mathrm{B} 0)$ and with B chromosomes $(\mathrm{B}+)$ for discriminative characters $(\mathrm{HFL}$, El, B/T, FI, IM3) analyzed at four localities in Yugoslavia. HFL - hind feet length, EL - ear length, B/T - relative tail length, FI - foramina incisiva length, IM3 - distance from 3rd upper molar to upper incisor), $n$ - number of animals, ${ }^{*}-p<0.02$.

\begin{tabular}{|c|c|c|c|c|c|c|c|c|c|c|}
\hline & & \multicolumn{2}{|c|}{ Jastrebac } & \multicolumn{2}{|c|}{ Cer } & \multicolumn{2}{|c|}{ Lešnica } & \multicolumn{2}{|c|}{ Ada } & \multirow[b]{2}{*}{$F_{(\mathrm{df1}, \mathrm{df} 2)}$} \\
\hline & & B0 & $\mathrm{B}+$ & B0 & $\mathrm{B}+$ & B0 & $\mathrm{B}+$ & B0 & $\mathrm{B}+$ & \\
\hline & $n$ & 104 & 78 & 35 & 20 & 21 & 11 & 40 & 11 & \\
\hline \multirow[t]{2}{*}{ HFL } & Min-Max & $15.83-24.60$ & $16.80-24.20$ & $20.58-24.05$ & $21.00-24.05$ & $19.48-23.95$ & $20.40-24.2$ & $20.40-25.25$ & $20.30-23.15$ & \\
\hline & Mean \pm SD & $21.93 \pm 1.28$ & $21.99 \pm 1.05$ & $21.96 \pm 0.74$ & $22.38 \pm 0.84$ & $22.20 \pm 1.12$ & $22.40 \pm 1.11$ & $23.06 \pm 1.00$ & $22.47 \pm 1.07$ & $F_{(1,318)}=0.002$ \\
\hline \multirow[t]{2}{*}{ EL } & Min-Max & $13.03-21.43$ & $12.73-21.38$ & $13.15-19.30$ & $12.65-20.15$ & $14.60-18.90$ & $14.30-18.70$ & $15.95-19.45$ & $16.30-17.90$ & \\
\hline & Mean \pm SD & $16.53 \pm 1.72$ & $16.71 \pm 1.68$ & $16.88 \pm 1.42$ & $16.45 \pm 1.77$ & $16.90 \pm 1.22$ & $16.39 \pm 1.88$ & $17.68 \pm 0.80$ & $17.00 \pm 0.56$ & $F_{(1,306)}=1.45$ \\
\hline \multirow[t]{2}{*}{$\mathrm{B} / \mathrm{T}$} & Min-Max & $0.80-1.31$ & $0.91-1.52$ & $0.91-1.30$ & $0.85-1.50$ & $0.91-1.22$ & $0.89-1.66$ & $0.83-1.21$ & $0.92-1.00$ & \\
\hline & Mean \pm SD & $1.10 \pm 0.09$ & $1.12 \pm 0.11$ & $1.06 \pm 0.10$ & $1.09 \pm 0.15$ & $1.06 \pm 0.10$ & $1.13 \pm 0.20$ & $1.00 \pm 0.08$ & $0.98 \pm 0.03$ & $F_{(1,277)}=6.35^{*}$ \\
\hline \multirow[t]{2}{*}{ FI } & Min-Max & $4.51-6.17$ & $4.14-6.10$ & $4.90-6.79$ & $4.41-5.78$ & $5.05-5.56$ & $4.95-5.88$ & $4.85-6.08$ & $5.19-5.98$ & \\
\hline & Mean \pm SD & $5.38 \pm 0.31$ & $5.35 \pm 0.38$ & $5.49 \pm 0.38$ & $5.30 \pm 0.36$ & $5.28 \pm 0.14$ & $5.43 \pm 0.34$ & $5.40 \pm 0.29$ & $5.43 \pm 0.30$ & $F_{(1,318)}=0.40$ \\
\hline \multirow[t]{2}{*}{ IM3 } & Min-Max & $10.75-14.73$ & $11.18-14.05$ & $11.60-14.00$ & $9.85-13.85$ & $11.55-13.70$ & $12.48-13.58$ & $11.15-14.13$ & $11.60-12.70$ & \\
\hline & Mean \pm SD & $12.79 \pm 0.79$ & $12.93 \pm 0.68$ & $12.85 \pm 0.66$ & $12.65 \pm 1.04$ & $12.86 \pm 0.54$ & $13.25 \pm 0.32$ & $12.87 \pm 0.78$ & $12.20 \pm 0.46$ & $F_{(1,318)}=0.63$ \\
\hline \multicolumn{2}{|l|}{$\% \mathrm{~B}$} & \multicolumn{2}{|c|}{42.9} & \multicolumn{2}{|c|}{36.4} & \multicolumn{2}{|c|}{34.4} & \multicolumn{2}{|c|}{21.6} & \\
\hline
\end{tabular}


(Jastrebac $-r=0.37$, Cer $-r=0.50$ and Lešnica $-r=0.48$ ) except on the Ada $(r=0.20)$ which has the smallest frequency $(21.6 \%)$ of animals with Bs. The last two localities (Lešnica and Ada) are less than $1 \mathrm{~km}$ apart. Although they are separated by a narrow river they have the same microhabitats. Thereby the obtained differences for FI and IM3 correlation among localities could be assigned to differences in frequencies of $\mathrm{B}$ chromosomes.

Populations with Bs are rare in A. sylvaticus and the additional frequency of specimens with Bs is low. Thus, problems with the presence of Bs could be neglected in this species. Contrary, in A. flavicollis, in which the frequency of animals with Bs varies from 0.11 to 0.64 in Yugoslavia (Vujošević et al. 1991, Vujošević and Blagojević 1994, M. Vujošević and J. Blagojević, unpubl.), the effects of Bs could be significant. A decrement of the frequency of animals with Bs produces consequently a decrement of the correlation between IM3 and FI. The effects of B chromosomes have additionally confused taxonomic determination in the Apodemus genus. Therefore, it is recommended that a morphological diagnosis is supported by karyological and/or electrophoretic data.

Acknowledgements: This work was partly supported by a research Science Funds of Serbia, Contract No. 03E02.

\section{References}

Blagojević J. and Vujošević M. 1991. Supernumerary chromosomes of Apodemus flavicollis (Rodentia, Mammalia). The highest number of B-chromosomes. Arhiv bioloških Nauka (Beograd) 43 (3-4): 31-32.

Blagojević J. and Vujošević M. 1995. The role of B-chromosomes in population dynamics of yellow necked wood mice Apodemus flavicollis (Rodentia, Mammalia). Genome 38: 472-478.

Felten H. 1952. Untersuchungen zur Ökologie und Morphologie der Waldmaus (Apodemus sylvaticus L.) und der Gelbhalsmaus (Apodemus flavicollis Melchior) im Rhein-Main-Gebiet. Bonner Zoolgische Beiträge 3: 187-206.

Görner M. and Hackethal H. 1987. Säugetiere Europas. Neumann Verlag, Leipzig: 1-371.

Kryštufek B. and Stojanovski L. 1996. Apodemus sylvaticus stankovici is a synonym of Apodemus flavicollis. Folia Zoologica 45: 1-7.

Niethammer J. 1969. Zur Frage der Introgression bei den Waldmäusen Apodemus sylvaticus und Apodemus flavicollis (Mammalia, Rodentia). Zeitschrift für Zoologishe Systematik und Evolutionsforschung 7: 77-127.

Ruprecht A. L. 1979. Kryteria identyfikacji gatunkowej podrodzaju Sylvemus Ognev \& Vorobiev 1923 (Rodentia: Muridae). Przegląd Zoologiczny 23: 340-349.

Seabright M. 1971. A rapid banding technique for human chromosomes. Lancet 11: 971-972.

Summner A. T. 1972. A simple technique for demonstrating centromeric heterochromatin. Experimental Cell Research 75: 304-306.

Tvrtković N. 1979. Razlikovanje i određivanje morfološki sličnih vrsta podroda Sylvemus Ognev \& Vorobiev 1923 (Rodentia, Mammalia). Rad Jugoslovenske akademije znanosti i umjetnosti 383: $155-186$.

Vorontsov N. N., Bekasova T. S., Kral B., Korobitsyna K. V. and Ivanitskaya E. Yu. 1977. On specific status of Asian wood mice of genus Apodemus (Rodentia, Mammalia) from Siberia and Far East. Zoologicheskii Zhurnal 56: 437-449. [In Russian with English summary]

Vujošević M. 1993. B-chromosomes in mammals. Genetika (Beograd) 25: 247-258. 
Vujošević M. and Živković S. 1987. Numerical chromosome polymorphism in Apodemus flavicollis and A. sylvaticus (Mammalia: Rodentia) caused by supernumerary chromosomes. Acta Veterinaria (Beograd) 37: 81-92.

Vujošević M., Blagojević J., Radosavljević J. and Bejaković D. 1991. B chromosome polymorphism in populations of Apodemus flavicollis in Yugoslavia. Genetica 83: 167-170.

Vujošević M. and Blagojević J. 1994. New localities with B chromosomes in Apodemus flavicollis (Rodentia, Mammalia). Archives of Biological Sciences (Beograd) 46 (3-4): 15.

Vujošević M. and Blagojević J. 1995. Seasonal changes of B-chromosome frequencies within the population of Apodemus flavicollis (Rodentia) on Cer mountain in Yugoslavia. Acta Theriologica 40: 131-137.

Zima J. and Macholán M. 1995. B chromosomes in the wood mice (genus Apodemus). Acta Theriologica, Supplement 3: 75-86.

Zima J., Macholán M. and Slivková L. 1997. Confirmation of the presence of B chromosomes in the wood mice (Apodemus sylvaticus). Folia Zoologica 46: 217-221.

Received 14 August 1998, accepted 19 April 1999. 